\title{
О ГЕОЛОГИЧЕСКОЙ КОРРЕЛЯЦИИ ДРЕВНЕБЕРЕГОВЫХ ОБРАЗОВАНИИ БАЛТИЙСКОГО МОРЯ В ЭСТОНИИ И ШВЕЦИИ
}

Уже в начале XVIII в. известный шведский натуралист У. Хярне писал, что на Балтике из-под воды со временем выходят опасные для морского плавания скалы, бывшие острова соединяются с сушей и рыбацкие деревни удаляются от берега моря (Hјärne, 1706). Он неверно объяснял эти факты постепенным понижением уровня моря вследствие уменьшения воды в морской впадине. Первым представителем идеи о подвижности земной коры в Финляндии оказался геодезист Э. О. Рунеберг, который пришел к заключению, что причиной регрессии моря является медленное поднятие суши (Runeberg, 1765). В 1848 г. об убыли воды в Балтийском море упоминалось также в материалах по Эстонии (Козакевич, 1848).

Эти высказывания были убедительно подтверждены позже многими исследователями, в том числе в геологических материалах по Эстонии. О тектоническом поднятии островов Западно-Эстонского архипелага вполне однозначно говорил, например, Э. Эйхвальд (1846), впервые упомянувший также и о находках раковин морских субфоссильных моллюсков в древнебереговых песках о-ва Хийумаa (Eichwald. 1853). Соответствующие находки и в других прибрежных районах Балтики дали возможность поднять вопрос о геологической корреляции древнебепеговых образований и бывших водоемов. Но высотные данные древнебереговых форм рельефа не дают такой возможности, потому что уже в первой половине прошлого века было обнаружено неравномерное поднятие Фенноскандии и его уменьшение с севера на юг. Были замечены также стабильные берега и погружающиеся районы, в частности на юге Швеции.

Большое значение в изучении субфоссильных моллюсков Балтийского моря имеют исследования академика Ф. Шмидта в Северной Эстонии. Он обнаружил, что эти моллюски встречаются только на сравнительно небольших абсолютных высотах (Schmidt, 1858). В 1869 г. он сообщил (Schmidt, 1869), что кроме морских моллюсков в древнебереговых образованиях на определенных высотах встречаются такие пресноводные формы. как Ancylus fluviatilis и Unio. Это открытие заинтересовало шведа X. Мунте, который выполнял соответствующие исследования на своем родном о-ве Готланд. И здесь на близких абсолютных высотах в 1887 г. он нашел пресноводную фауну моллюсков, что заложило научную основу для геологической корреляции древнебереговых образований и позволило в дальнейшем выделить в развитии Балтийского моря стадии Иольдиевого моря, Анцилового озера и Литоринового моря (Munthe, 1910).

K настоящему времени геологические методы настолько усовершенствовались, что появилась возможность точно определить как возраст древнебереговых образований (радиоуглеродным, палинологическим и 
другими методами), так и пространственно-временные особенности движений земной коры. Появилась также возможность надежной корреляции не только стадиальных, но и фазиальных отложений Балтики. Появление разработанных новых способов и установок для бурения морского дна позволило приступить также к корреляции над- и подводных отложений и форм рельефа.

Новые возможности корреляции опорных уровней Анцилового озера, Литоринового и Лимниевого морей между Швецией и Эстонией открывались в связи с выходом новейших публикаций шведских исследователей (Königsson, 1967; 1968; Borg и др., 1979; Königsson, Olsson, 1981; Persson, 1978) на о-вах Готланд и Эланд и в районе Стокгольма (Persson, 1979; Miller, Robertsson, 1981; Miller, 1981).

Характер древних берегов Балтийского моря и их развитие в послеледниковое время в Западной Эстонии и на больших островах Восточной Швеции весьма сходны. В северо-западной части Эстонии и на о-ве Готланд, где абсолютные высоты достигают $45-55$ м, береговые образования пребореального Иольдиевого моря обнажаются только в небольшой прибрежной полосе. В значительной части сравниваемых территорий образования Иольдиевого моря находятся ниже образований анциловой трансгрессии. О приблизительном возрасте (примерно от 9700 до 9500 л.н.) кульминации трансгрессии Иольдиевого моря можно судить по датировкам погребенных органогенных отложений Юго-Западной Эстонии (Кессел, Пуннинг, 1969а). Радиоуглеродный возраст иольдиевых отложений на о-ве Готланд пока не установлен.

Как известно, в развитии Балтики в конце пребореала выделяется трансгрессия Рабдонемового (Thomasson, 1927) или Эхенейсового моря (Sauramo, 1958), которая занимает переходное положение между иольдиевой и анциловой стадиями, когда бассейн Балтики имел ограниченный контакт с Мировым океаном. По материалам Западной Эстонии, видимо, погребение органогенных отложений произошло в начале бореала во время кульминации трансгрессии Эхенейсового моря в разрезах Леммеоя от 9800 до 9100, Выйду около 9000, Тапу сколо 9000 л. н. (рис. $1,1-3)$, на о-ве Сааремаа в разрезе Тыризе и в Северной Эстонии в разрезе Муукси около 9300 л. н. (рис. 1, 4-5). По радиоуглероду определен такой же возраст торфа (около 9200 л. н.) из-под анцилового берегового вала в юго-западной части о-ва Готланд в местонахождении Фрейель (рис. 1, 6) (Lundqvist, 1965). В последние годы повторно изучены возрастные соотношения погребенных торфов в южной части о-ва Готланд, в районе Бурге (Persson, 1978). В Голлвотере и Фардгеме (рис. 1, 7 и 8) были найдены погребенные торфы, возникшие примерно $10200-9300$ л. н. К. Персон сопоставляет погребение их с анциловой трансгрессией, которая может быть аналогом эхенейсовой в нашем понимании. Ранее, ссылаясь на аналогичные материалы о-ва Готланд, предполагали существование первой и второй анциловых трансгрессий (Lundqvist, 1965). К. Персон рассматривает описанные Г. Лундквистом органогенные отложения в Сялмюре (рис. 1,9) как аллохтонные и отрицает возможность существования двух анциловых трансгрессий на о-ве Готланд.

Л.-К. Кэнигсон (Königsson, Olsson, 1981) недавно установил возраст радиокарбона раковин субфоссильных моллюсков, находящихся в береговых отложениях примерно на 25 м ниже максимального уровня Анцилового озера на о-вах Готланд и Эланд, соответственно около $10200-10500$ и $10000-8500$ л. н. Шведские ученые предполагают, что эта фауна моллюсков развивалась немного позднее катастрофического спуска Биллингена или в начале возникновения Иольдиевого моря, когда влияние соленой воды Атлантического океана через пролив было незначительным. По нашему мнению, оценка возраста раковин завы- 


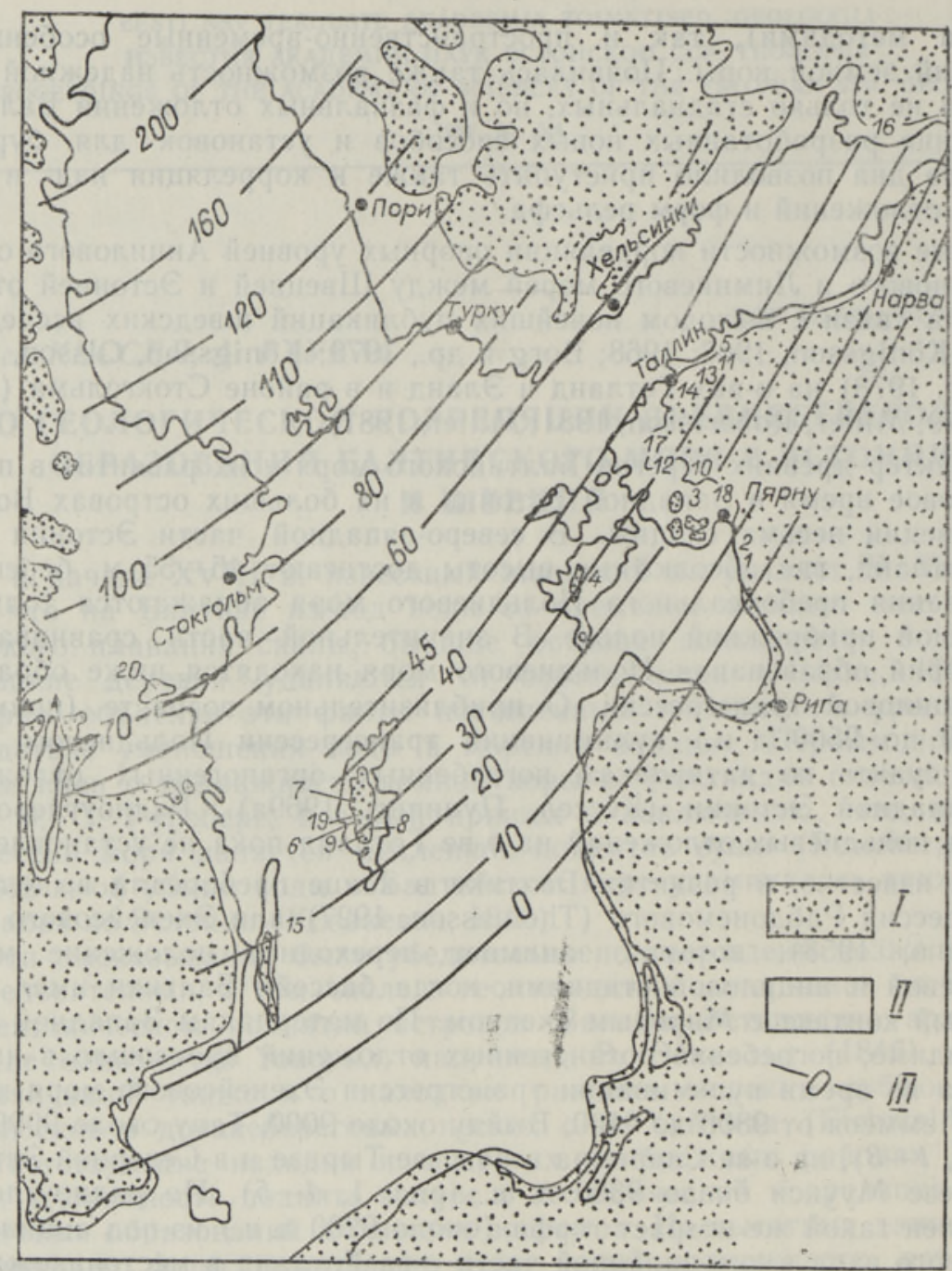

Рис. 1. Местонахождения погребенных органогенных отложений пол береговыми образованиями Аншилового озера: 1 - Леммеоя, 2 - Выйду, 3 - Тапу, 4 - Тыризе, 5 - Муукси. 6 - Фрейель. 7 - Голлвотер, 8 - Фардгем. 9 - Сялмюр, 10 - Алткюла, 11 - Қахала, 12 - Охтла, 13 - Иыэляхтме, 14 - Юлемисте, 15 - о-в Эланд, болото Скеде Мосе, 16 - Лужки, 17 - Паливере, 18 - Кыду, 19 - Мальмс, 20 Норчёпинг. Условные обозначения: I - суша во время распространения Анцилового озера (Литоринового моря). II - акваторня Анцилового озера (Литоринового моря) и III - изобазы Анцилового озера (Литоринового моря) в метрах.

шена из-за характера изученного материала и фауна моллюсков принадлежит к анциловому бассейну.

Неотектоническое поднятие в Средней Швеции в бореале нарушило связь с океаном, и в Балтийской котловине образовалось Анциловое озеро, которое постепенно опреснялось за счет притока речных и талых ледниковых вод. Озеро трансгрессировало автономно, независимо от эвстатических колебаний уровня Мирового океана. Предполагают, что Анциловое озеро существовало в то время, когда ледниковый покров сохранялся только на крайнем севере Швеции. В это время была затоплена бо́льшая часть Западной Эстонии и о-вов Сааремаа и Хийумаа. Найденные в береговых отложениях Анцилового озера пресноводные моллюски (Ancylus fluviatilis и др.) указывают, что высшая 
граница этого водоема в Ӭстонии (Ḱessel, 1977) и на о-вах Готланд и Эланд (Königsson, 1964; Königsson, 1967) была сходна. Установлено, что после регрессии Эхенейсового моря и здесь, в прибрежной полосе, началось торфообразование. Например, погребенные органогенные отложения в Юго-Западной Эстонии, где проходит анциловая изобаза А20, в разрезе Алткюла (рис. 1, 10) имеют возраст около 8500 л. н., в Северной Эстонии в разрезах Қахала, Охтла и Йыляхтме (рис. 1, 11-13) около $8500-8700$ л.н., а в анциловых лагунах Юлемисте (рис. 1,14 ) и Йыэляхтме осадконакопление органогенных отложений началось около 8400-8200 л. н. (Кессел, Пуннинг, 1969б).

Соответствующие датировки погребенных органогенных отложений на о-ве Готланд отсутствуют. Сообщали (Königsson, 1968), что возраст начала анциловой трансгрессии на о-ве Эланд - около 9500 л. н. На основании изучения прибрежного озера Скеде Мосе (средняя часть о-ва Эланд, анциловая изобаза А20 м, рис. 1, 15), возраст кульминации анциловой трансгрессии был около 8800 л. н. Значения датировок на анциловых изобазах около А20 м, например в местонахождениях Алткюла и Скеде Мосе, очень сходны. На основании такой корреляции выясняется, что образец отложений бывшего прибрежного озера Йыэляхтме на 500 лет моложе кульминации трансгрессии на о-ве Эланд.

Далее уместно осветить результаты изучения голоценовых бассейнов Балтики в Ленинградской области, где анциловые изобазы проходят на абсолютных высотах от 25 до 30 м. К югу от Приморска (в районе Койвисто, Лужки, рис. 1, 16) пробурена скважина и отобран образец на радиоуглеродное датирование из верхнего слоя погребенного торфа с глубины около 20 м (Знаменская, Черемисинова, 1974; Долуханов, Знаменская, 1965). Датировка этого торфа, $8400 \pm 200$ л. н., близка к датировкам погребенного торфа в Западной и Северной Эстонии, в частности в Йыэляхте, Паливере и Кыду (рис. 1, 13, 17 и 18).

В разрезе Лужки результаты диатомового анализа показали, что погребенный торф разделяет два горизонта прибрежных отложений Анцилового озера. Ниже торфа прибрежные отложения с растительными остатками первой половины бореала содержат типичную анциловую диатомовую флору с незначительным содержанием морских форм диатомовых, как Melosira, sulcata, Hyalodiscus scoticus и обломки Centrales. Еще ниже отложения более глинистые и содержат солоноводную морскую флору диатомовых, типичную для пребореального Иольдиевого моря. Таким образом, в рассматриваемом районе происходила непрерывная аккумуляция отложений Иольдиевого моря и первой фазы Анцилового озера вплоть до его регрессии. Выше торфа встречаются трансгрессивные отложения второй половины бореала, т. е. собственно анциловой фазы, которые представлены песчаными отложениями с прослойками гальки.

Весьма важное для выяснения развития Анцилового озера местонахождение известно на той же абсолютной высоте в северо-восточной части Приладожья, в районе Питкаранта, где под анциловым береговым валом найден торфяник, образовавшийся $8690 \pm 100$ л. н. (Знаменская, Черемисинова, 1974). Это значение близко датировке погребенного торфа Йэляхтме, как отмечено выше.

Следовательно, результаты изучения продолжительности и возраста анциловой трансгрессии в Эстонии и Ленинградской области очень хорошо совпадают. Следует упомянуть, что в результате более ранних изучений (Lundqvist, 1965) на о-ве Готланд в Сялмюре и Мальмсе (рис. 1, 9 и 19) также определен возраст погребенных торфяников около 8500 и 8400 л. н., что хорошо согласуется с датировками погребенных отложений в Эстонии и Ленинградской области. 


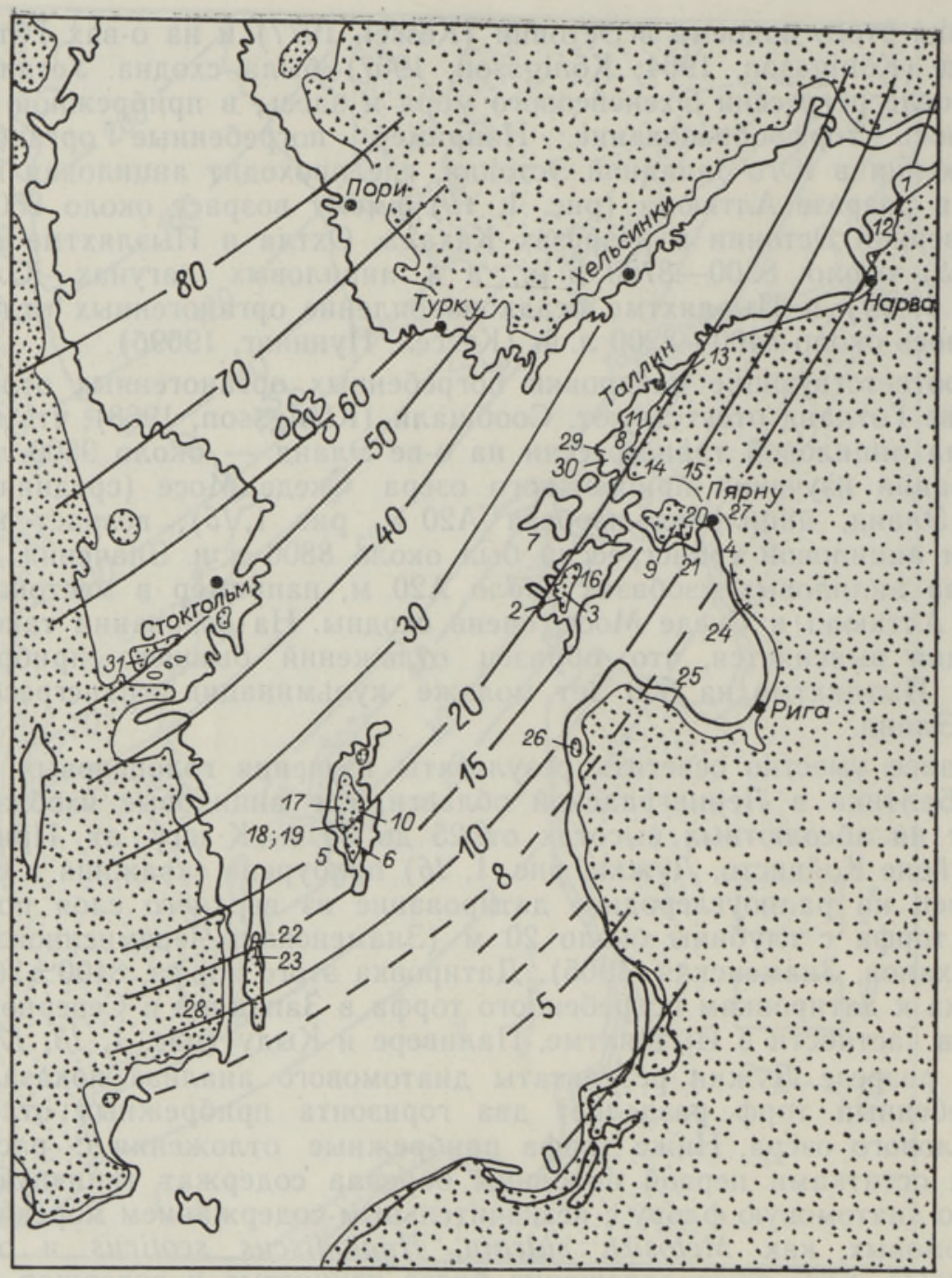

Рис. 2. Местонахождения погребенных органогенных отложений под береговыми образованиями Литоринового моря и основных лагун Лимниевого моря: 1 - Сосновый Бор, 2 - Везику, 3 - Кярла, 4 - Раннаметса, 5 - Мястермюр, 6 - Тянгдарве, 7 - о-в Хийумаа, болото Қыйвасоо, 8 - болото Нийтвялья, 9 - Колга, 10 Дюниссе, 11 - Кейла-Йоа, 12 - Молодежное, 13 - болото Хара, 14 - Яризе, 15 - Вигала, 16 - о-в Сааремаа, Рэо, 17 - Снодер, 18 - Мяллингсюр, $19-$ Геллмюр, 20 - Оара, 21 - Селисте, 22 - Мэлыза, 23 - Ывре-Сандби, 24 - Светупе, 25 - Гипка, 26 - Варве, $27-$ Синди, $28-$ Халларумс, 29 - болото Нийби, 30 - болото Эльбику, 31 - Нючёпинг.

Следует сказать, что районы Койвисто, Иыэляхтме, Паливере и Бурге (о-в Готланд) находятся на почти одинаковых абсолютных высотах, т. е. в пределах анциловых изобаз от А35 до А28 м. Таким обра. зом, геологическое развитие Балтики должно было быть аналогичным в вышеназванных районах.

Изучены комплексно (Persson, 1979) шесть разрезов торфяников, находящихся на абсолютных высотах от 50 до 100 м в районе Норчёпинга (рис. 1,20 ). По взаимоотношению между формами пресноводных и солоноводных диатомовых, палинологическим данным и радиоуглеродным датировкам органогенных слоев установлены постепенное понижение уровня водоема и потери связи с мороким бассейном в конце 
пребореала и в течение бореала от 10400 до 8500 л. н. Это было время существования Анцилового озера, возраст которого оказывается в данном случае очень ранним. К. Персон объясняет это локальными экологическими условиями в небольшом прибрежном озере, ссылаясь на аналогичные результаты исследований в близрасположенном местонахождении Студылен (Florin, 1977).

Общеизвестно, что во второй половине анциловой стадии началась регрессия Балтики, что привело к осушению обширных прибрежных полос и торфообразованию. После регрессии Анцилового озера произошло проникновение морских вод в Балтийскую котловину. Переход к новой продолжительной стадии, получившей, по характерному моллюску Littorina littorea, название литориновой, прослеживается по увеличению роли солоновато-водных диатомей и моллюсков наряду с уменьшением роли пресноводных представителей.

Начало торфообразования прибрежных полос датировано в нескольких разрезах, покрытых литориновыми береговыми образованиями, что позволило установить начало регрессии и конец анциловой стадии. Самые древние органогенные отложения, залегающие под анциловыми береговыми отложениями, датированы в Ленинградской области в разрезе Сосновый Бор (рис. 2, 1) и в Западной Эстонии, в разрезах Везику, Кярла и Раннаметса (рис. 2, 2-4) (Кессел, Пуннинг, 1976), на о-ве Готланд, в разрезах Мястермюр и Тянгдарве (рис. 2, 5 и 6) (Persson, 1978) от 7800 до 8000 л. н.

Регрессия Анцилового озера продолжалась до стадии Мастоглойевого моря. В связи с мастоглойевой трансгрессией в разрезе Кыйвасоо о-ва Хийумаа (рис. 2, 7), в разрезе Нийтвялья Северо-Западной Эстонии (рис. 2, 8) и в разрезе Колга Юго-Западной Эстонии (рис. 2, 9) произошли аккумуляция и погребение лагунных отложений с мастоглойевой диатомовой флорой. Осадконакопление в прибрежных озерах или лагунах началось примерно от 8000 до 7500 л. н. Близкий возраст иммиграции полупресноводной диатомовой флоры установлен в районе Стокгольма (Persson, 1979), в Южной Финляндии (Eronen, 1974) и в Западной Әстонии (Кессел, Порк, 1974; Sarv и др., 1982). Г. Лундквист относил начало мастоглойевой стадии на о-ве Готланд примерно ко времени 7500 л. н. (Lundqvist, 1965).

B сравниваемых нами прибрежных районах, например, разрез Кярла о-ва Сааремаа органогенные отложения мастоглойевой стадии непрерывно накоплялись от 7800 до 7000 л. н., в разрезе Дюниссе о-ва Готланд (рис. 2, 10) торфообразование происходило аналогично, от 7800 до 7200 л.н. (Lundqvist, 1965). Почти в то же самое время (около 7200 л.н.) происходило торфообразование в Северной Эстонии (разрез Кейла-Иоа, рис. 2, 11), около 7400 л. н. в Ленинградской области (разрез Молодежное, рис. 2, 12) и погребение этих разрезов под литориновыми прибрежными отложениями. Следует отметить, что в последнем разрезе торфообразование окончательно прекратилось 7100 л. н. На основании этих датировок начало ранней литориновой трансгрессии относят ко времени около 7200 л. н. и кульминацию ее - около 6800 л. н., например, местонахождения Хара, Яризе, Вигала, Кярла и Рэо в Северной и Западной Эстонии (рис. 2, 13-16).

По последним датировкам к такому же возрасту (от 6900 до 6700 л.н.) относят органогенные отложения о-ва Готланд в местонахождениях Снодер (рис. 2, 17), Мястермюр и Тянгдарне (Persson, 1978). По прежним исследованиям возраста ранней литориновой трансгрессии в разрезах Снодер, Дюниссе, Мяллингсмюр и Геллмюр этого острова (рис. 2, 18 и 19), отложения были более молодыми, в интервале эт 6600 до 6400 л. н. (Lundqvist, 1965).

Литориновая стадия соответствует послеледниковому климатическому оптимуму. В это время полностью растаяли ледники на Сканди- 
навском нагорье. Трансгрессия Литоринового моря была сложной. Разные исследователи выделяют несколько последовательно сменявших друг друга фаз повышения уровня Литоринового моря. Амплитуды трансгрессий, в связи с более интенсивным неотектоническим поднятием Фенноскандии, убывали к северу. Береговые линии Литоринового моря максимально прослеживаются в районе Стокгольма на абсолютной высоте около 50 м, и ранние фазы литориновых трансгрессий в этом районе Швеции слабо выражены (Persson, 1979).

По результатам самых последних изучений (Miller, Robertsson, 1981; Miller, 1981) известно, что в районе Стокгольма происходили повторно литориновые трансгрессии, сходные по возрасту с трансгрессиями в пределах литориновых изобаз от L30 до L20 в более северо-восточной части Балтики. Так, трансгрессия Ll близ Нючёпинга (рис. 2, 31) совпадает с ранней литориновой трансгрессией на о-ве Готланд и в северо-западной части побережья Эстонии. Трансгрессия L2 в пределах литориновых изобаз от L20 до L10 м также почти одновременна с трансгрессией $\mathrm{L}_{\text {пь }}$ на о-вах Сааремаа и Готланд. Трансгрессия, по вышеуказанным исследованиям, несколько более поздняя, чем перемещение уровня $\mathrm{L}_{\mathrm{III}}$ в Әстонии, где отсутствуют признаки трансгрессивного характера моря в этом же промежутке времени. Аналогичной корреляции поддается трансгрессия L4 с максимальным уровнем Лимниевого моря в самой северо-западной части Әстонии (Нийби и Эльбику, рис. 2, 29 и 30). Еще более поздние перемещения уровня воды Балтики в районе Стокгольма представлены двумя стагнациями уровня соответственно около 2400 и 1000 л. н. В Эстонии в это время существовали регрессивные лимниевые фазы Lim

Имеющиеся в нашем распоряжении радиоуглеродные датировки не позволяют составить достаточно полного представления о развитии трансгрессии Литоринового моря. Пока в атлантике и суббореале Эстонии можно наметить три небольшие трансгрессии, в Ленинградской области только одну, в Латвии и в Литве три-четыре, на о-вах Готланд и Әланд - до двух, а в Южной Швеции - до шести солоноводных трансгрессивных фаз Литоринового моря.

В средней атлантике Әстонии наблюдалась поздняя литориновая трансгрессия. Погребенные в результате этой трансгрессии отложения установлены в разрезах Везику, Оара и Селисте (рис. 2, 20 и 21). Датировки их от 6400 до 6000 л.н. На о-ве Готланд литориновая трансгрессия зафиксирована в нескольких разрезах также в диапазоне от 6400 до 6000 л. н. (Lundqvist, 1965). На о-ве Эланд в разрезах погребенных торфяников Мэлыза и Ывре-Сандби (рис. 2, 22 и 23) отложения датированы около 6400 л. н. (Königsson, 1964). В работе К. Персона (Persson, 1978) представлен разрез Тянгдарне, абсолютная высота которого около 14 м. Здесь торфообразование происходило в интервале от 8100 до 7000 л. н. В Западной Эстонии на аналогичных абсолютных высотах органогенные отложения были погребены значительно позднее, около $6500-6000$ л. н.

По исследованиям Б. Берглунда (Berglund, 1971), в Восточном Блекинге в интервале от 7000 до 4000 л. н. установлены шесть литориновых трансгрессий. Некоторые из них сопоставимы с изученными нами литориновыми трансгрессиями на побережье Латвии, например, в разрезах Светупе, Гипка и Варве (рис. 2, 24-26) (Гринбергс и-др., 1975). Однако около Пярну прослежены торфяники Оара и Синди (рис. 2, 20 и 27), развивавшиеся беспрерывно от 7200 до 5000 л. н. На о-ве Эланд, где береговые образования Литоринового моря в пределах болота Ресмо синхронны по абсолютным высотам с образованиями около Пярну, установлена только одна трансгрессия (Borg и др., 1979). Следует отметить, что Л.-К. Кэнигсон отрицает возможность проявле- 


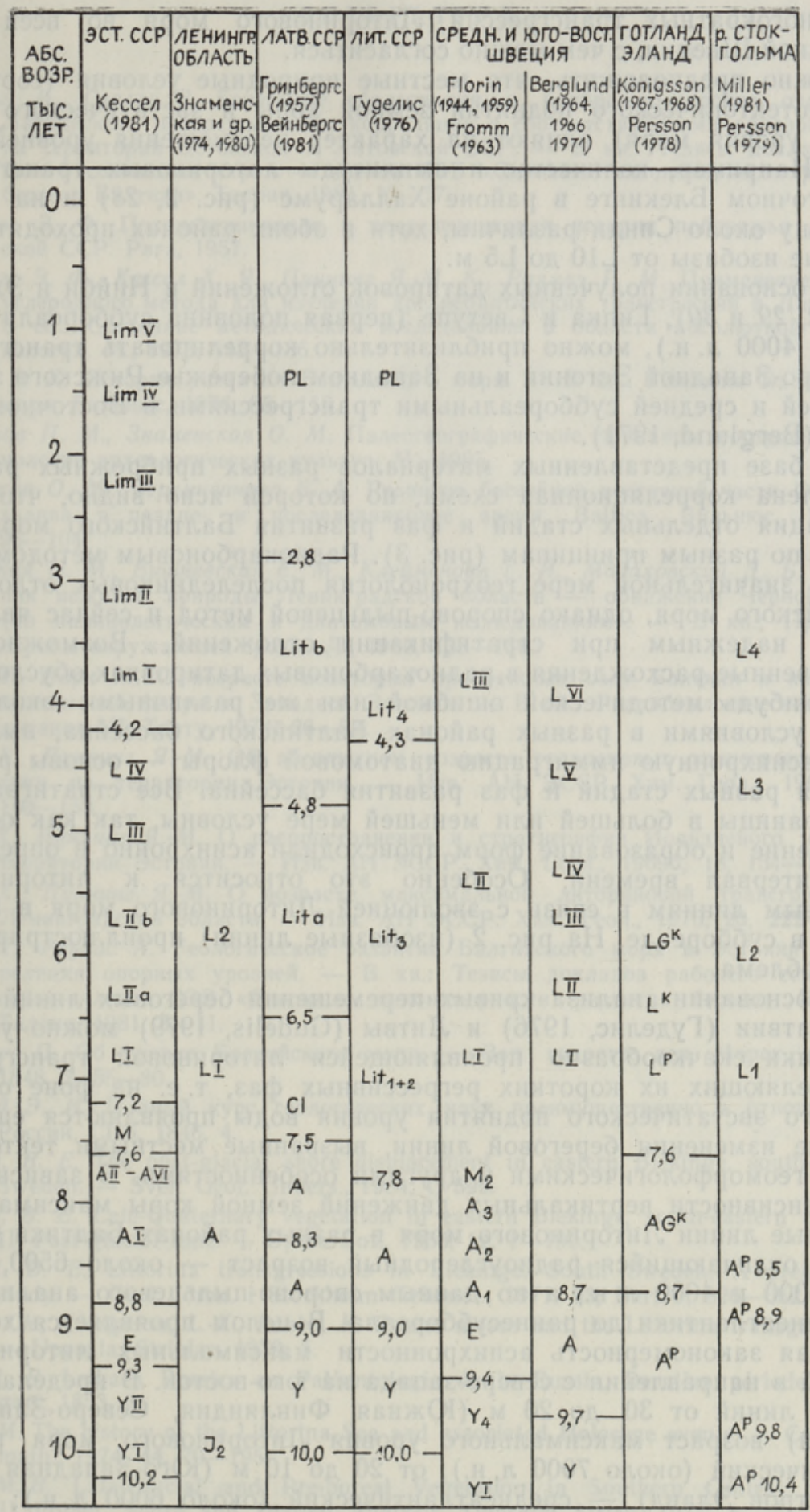

Рис. 3. Корреляция опорных уровней (стадий развития) послеледниковых водоемов Балтики. Условные обозначения: У - Иольдиевое море, Е - Эхенейсовое море, А Анциловое озеро, M - Мастоглойевое море, L - Литориновое море, Lim - Лимниевое море, PL - Постлиториновое море. 
ния многократных трансгрессий Литоринового моря во всей ЮгоВосточной Швеции, с чем можно согласиться.

Можно предположить, что местные природные условия (соотношение неотектонического поднятия земной коры и эвстатического повышения уровня моря) влияют на характер перемещения уровней Балтики. Например, количество и амплитуды литориновых трансгрессий в Восточном Блекинге в районе Халларумс (рис. 2, 28) и на берегу р. Пярну около Синди различны, хотя в обоих районах проходят литориновые изобазы от L10 до L5 м.

На основании полученных датировок отложений в Нийби и Эльбику (рис. 2, 29 и 30), Гипка и Светупе (первая половина суббореала около 4500 и 4000 л. н.), можно приблизительно коррелировать трансгрессии в Северо-Западной Эстонии и на Западном побережье Рижского залива с ранней и средней суббореальными трансгрессиями в Восточном Блекинге (Berglund, 1971).

На базе представленных материалов разных прибрежных районов составлена корреляционная схема, по которой ясно видно, что стратификация отдельных стадий и фаз развития Балтийского моря проведена по разным принципам (рис. 3). Радиокарбоновым методом уточнена в значительной мере геохронология послеледниковых отложений Балтийского моря, однако спорово-пыльцевой метод и сейчас является самым надежным при стратификации отложений. Возможно, что существенные расхождения в радиокарбоновых датировках обусловлены какой-нибудь методической ошибкой или же различными экологическими условиями в разных районах Балтийского бассейна, вызывавшими асинхронную иммиграцию диатомовой флоры - основы разграничения разных стадий и фаз развития бассейна. Все стратиграфические границы в большей или меньшей мере условны, так как осадконакопление и образование форм происходили асинхронно в определенный интервал времени. Особенно это относится к литориновым береговым линиям в связи с эволюцией Литоринового моря в атлантике и в суббореале. На рис. 2 (изобазные линии) проиллюстрирована эта проблема.

На основании анализа кривых перемещения береговых линий Әстонии, Латвии (Гуделис, 1976) и Литвы (Gudelis, 1979) можно установить пики скачкообразно проявляющейся литориновой трансгрессии и разделяющих их коротких регрессивных фаз, т. е. на фоне общего крупного эвстатического поднятия уровня воды проявляются еще локальные изменения береговой линии, вызванные местными тектоническими, геоморфологическими и другими особенностями. В зависимости от интенсивности вертикальных движений земной коры максимальные береговые линии Литоринового моря в разных районах Балтики имеют сильно отличающийся радиоуглеродный возраст - около 6500, 6000, 5500,5000 и 4000 л. н., а по данным спорово-пыльцевого анализа, от среднеатлантики до раннесуббореала. В целом проявляется хорошо уловимая закономерность асинхронности максимальных литориновых уровней в направлении с северо-запада на юго-восток. В пределах изобазных линий от 30 до 20 м (Южная Финляндия, Северо-Западная Эстония) возраст максимального уровня Литоринового моря раннеатлантический (около 7000 л.н.); от 20 до 10 м (Юго-Западная Эстония, остров Эланд) - среднеатлантический (около 6000 л.н.); от 10 до 5 м (Западная Латвия, Блекинге) - позднеатлантический (около 5000 л. н.) и ниже 5 м (ПНР, ГДР) - раннесуббореальный (около 4000 л. н.). 
Вейнбергс Н., Стелле В. Береговые образования и прибрежно-морские отложения Латвийского побережья и их коррелящии с соответствующими образованиями на территории Эстонской и Литовской ССР. - В кн.: Тезисы докладов рабочего совещания стран - членов СЭВ «Основные закономерности развития берегов Балтики». Таллин, 1981, 12-17.

Гринбергс Э. Ф. Позднеледниковая и послеледниковая история побережья Латвийской ССР. Рига, 1957.

Гринбергс Э. Ф., Кессел Х. Я., Пуннинг Я.-М. К., Раямяэ Р. М. Применение радиоуглеродного метода для изучения древнебалтийских трансгрессий в Латвии. В сб.: Состояние методических исследований в области абсолютной геохронологии. М., 1975, 182-186.

Гуделис В. К. История развития Балтийского моря. - В кн.: Геология Балтийского моря. Вильнюс, 1976, 95-116.

Долуханов П. М., Знаменская О. М. Палеогеографические принципы построения хронологии археологических культур. М., 1965.

Знаменская O. М., Черемисинова E. A. Развитие бассейнов восточной части Финского залива в поздне- и послеледниковое время. Baltica. Вильнюс, 1974, 5, $95-104$.

Знаменская О. М., Вииневская Е. М., Клейменова Г. Н., Малаховский Д. Б. Памятник неживой природы Ленинградской области - обнажение Черной речки (по палинологическим и диатомовым исследованиям). - В кн.: Проблемы охраны окружающей среды. Л., 1980, 133-156.

Кессел X., Порк М. О возрасте некоторых прибрежных озер Балтики и характере диатомовой флоры в Западной Эстонии, - В сб.: Гидробиологические исследования VI. Тарту, 1974, 26-50.

Кессел Х., Пуннинг Я.-М. Об абсолютном возрасте голоценовых трансгрессий Балтики на территории Эстонни. - Изв. АН ЭССР. Хим. Геол., 1969а, 18, $140-153$.

Кессел Х., Пуннине Я.-М. О распространении и стратиграфии Иольдиевого моря на территории Эстонии. - Изв. АН ЭССР. Хим. Геол., 19696, 18, 154-163.

Кессел Х., Пуннинг Я.-М. О возрасте максимальной литориновой трансгрессии в Ленинградской области. - Изв. АН ЭССР. Хим. Геол., 1976, 25, 222-229.

Кессел X., Раукас A. Геологическое развитие Балтийского моря в Эстонии и корреляция опорных уровней. - В кн.: Тезисы докладов рабочего совещания стран-членов СЭВ «Основные закономерности развития берегов Балтики. Таллин, 1981, 5-11.

Козакевич П. Об уровне Балтийского моря. - Зап. гидрогр. деп. Морск. минист., $1848,2,55-80$.

Эйхвальд Э. И. Полный курс геологических наук преимущественно в отношении к России. СПб, 1846, 4.

Berglund, B. E. The post-glacial shore displacement in eastern Blekinge, south-eastern Sweden. - Sver. Geol. Unders., 1964, C 599.

Berglund, B. E. Late-Quaternary vegetation in eastern Blekinge, south-eastern Sweden. II. Post-glacial time. - Opera Bot., 1966, 12, 1-190.

Berglund, B. E. Littorina transgressions in Blekinge, South Sweden. A preliminary study. - Geol. fören. i Stockholm förhandl., 1971, 93, Part 3, 626-652.

Borg, C. Ch., Königsson, L.-K., Paabo, K. Resmo mosse and the Littorina transgressions. - Uppsala, Striolae, 1979, 5.

Eichwald, E. Lethaea Rossica en Paléontologie de la Russie, Dernière période. Stuttgart, 1853, 3.

Eronen, $M$. The history of the Littorina Sea and associated Holocene events. - Comment. math., 1974, 44, 79-195.

Florin, M.-B. Late-Glacial and Pre-boreal Vegetation in Southern Central Sweden. II Pollen, Spore and Diatom Analysis. Uppsala, Striae, 1977, 5.

Florin, S. Havstnandens Förskjutningar och bebyggelseutvecklinggen i östra Mellansverige under senkvartär tid. I. Allmän översikt. - Geol. fören. i Stockholm förhandl., 1944, 66, 551-634.

Florin, S. Hagtorp. En prekeramisk kvartsförande făngstboplats från tidig Littorinatid. - Uppsala univ., 1959, 5, 7-51.

Fromm, E. Absolute chronology of the late Quaternary Baltic. I. Baltica. Vilnius, 1963, $46-59$. 
Gudelis, V. The Quaternary history of the Baltic. Lithuania. - Acta Univ. Ups. Symp. Ups. Ann. Quing. Cel., 1979, 1, 159-173.

Hjärne, $U$. Den beswarade och förklarade anledningens andra flock, om jorden och landskap i gemeen. - In: Den korta anledningen, til ätskillige malm och bergarter, mineraliers och jordeslags etc. eftersporjande och angifwande, beswarad och förklarad. Stockholm, 1706, 133-416.

Kessel, H. Ober die Küstenverschiebungen des Ancylussees in Estland im Lichte der vertikalen Verbreitung von Ancylus fluviatilis. Baltica. Vilnius, 1977, 6, $53-64$.

Königsson, L.-K. Ancylus fluviatilis und ancylusführende Ablagerungen auf Öland. -Geol. fören. i Stockholm förhandl., 1964, 85, 381-390.

Königsson, L.-K. Die Datierung von baltischen Ancylus-Lagern der höchsten AncylusGrenze auf Gotland und Oland. - Geol. fören i Stockholm förhandl., 1967, $89,133-150$.

Königsson, L.-K. The Ancylus Transgression in the Skede Mose Area, Oland. - Geol. fören. i Stockholm förhandl., 1968, 90, 5-36.

Lundqvist, G. C ${ }^{14}$-dateringar från Gotland. - Sver. Geol. Unders., 1965, ser. C., $94-103$.

Miller, U. A. Method of Reconstructing Changes in the Sedimentation Environment. Report on the Meeting of Research Group Biology (24.-25. March 1980 , Paris) and Statements, 1981, AS (Science) Pact (31) 3, 40-52.

Miller, U., Robertsson, A.-M. Current biostratigraphical studies connected with archeological excavations in Stockholm region. - In: Florilegium Florinis Dedicatum. Uppsala, Striae, 1981, 14, 8-9.

Munthe, $H$. Studies in the Late-Quaternary history of Southern Sweden. - Geol. fören. i Stockholm förhandl., 1910, 32, 1197-1292.

Persson, Ch. Dateringar av Ancylus- och Littorinatransgressionerna på södra Gotland. - Sver. Geol. Unders., 1978, C 745.

Persson, Ch. Shore displacement during Ancylus time in the Rejmyra area South Central Sweden. - Sver. Geol. Unders., 1979, C 72, N 17.

Runeberg, E. Anmärkningra, om någre förändringar på jordeytarr i allmänhet, och under de kalla climit i suunerhet. - Kungl. Svenska Vet. Akad., 1765, 26, 81-115.

Sarv, A., Pork, M., Ilves, E. Stratigraphy and chronology of lake and bog deposits of the Kõivasoo Bog. - In: Peatland Ecosystems, Tallinn, 1982, 148-163.

Sauramo, M. Die Geschichte der Ostsee. - Ann. Acad. Scient. fennicae. Ser. A, III. Geol.-Geograph., Helsinki, 1958, 51.

Schmidt, F. Untersuchungen über die Silurische Formation von Ehstland, Nord-Livland und Oesel. - Arch. Naturk. Liv-, Ehst- u. Kurl., 1858, Ser. 1, Bd. 2.

Schmidt, F. Notiz über neuere Untersuchungen im Gebiete der Glacial- und Postglacialformation in Estland und Schweden. - In: Helmersen, G. Studien über die Wanderblöcke und die Diluvialgebiete Russland. Mém. Acad. Sci. St.-Petersb., 1869 , ser. $7,14,55-59$.

Thomasson, H. Baltiska tidsbestämningar och baltisk tigsindelning vid Kalmarsund. Geol, fören. i Stockholm förhandl., 1927.

\author{
Ннститут геологии \\ Академии наук Эстонской ССР
}

Поступила в редакцию

$21 / \mathrm{X} 1983$

Helgi KESSEL, A. RAUKAS

\title{
LAANEMERE VANADE RANNAMOODUSTISTE KORRELATSIOON EESTIS JA ROOTSIS
}

Artiklis on antud ülevaade Eestis ja Rootsis olevate Läänemere vanade rannamoodustiste vanuselise rööbistamise ajaloost ning esitatud uus korrelatsiooni skeem (joon. 3), kus võrdluseks on toodud andmed ka Läti, Leedu ja Leningnadi oblasti kohta. On järeldatud, et Joldiamere transgressioon Eestis ja Kesk-Rootsis leidis aset 9700-9500, Antsülusjärve transgressiooni kulminatsioon oli u. 8700 ja Mastogloiamere transgressiooni kulminatsioon u. 7600 aastat tagasi (= a. t.). Sôltuvalt rannamoodustiste iso- 
baasjoonte kõrgustest avalduvad Antsülusjärve ja Litoriinamere transgressioonide kulminatsioonid erinevalt (joon. 1 ja 2). Näiteks isobaasjoonte piires $30-20 \mathrm{~m}$ üle merepinna oli Litoriinamere transgressioon varaatlantiline (u. 7000 a. t.), isobaasjoonte piires $20-10 \mathrm{~m}$ keskatlantiline (u. 6000 a. t.), isobaasjoonte piires $10-5 \mathrm{~m}$ aga hilisatlantiline (u. 5000 a. t.).

\section{Helgi KESSEL, A. RAUKAS}

\section{CORRELATION OF THE BALTIC ANCIENT COASTAL FORMATIONS IN ESTONIA AND SWEDEN}

The paper deals with the correlation history of the Baltic ancient coastal formations in Estonia and Sweden and presents a new correlation scheme (Fig. 3) where the data from Latvia, Lithuania and Leningrad Region are brought for comparison. The conclusion has been reached that in Estonia and Sweden the Yoldia transgression took place $9700-9500$ years ago, the Ancylus transgression culminated about 8700 years ago and the Mastogloia transgression approximately 7600 years ago. In dependence on the absolute height of the isolines of coastal formations, the Ancylus and Littorina transgressions culminated differently (Figs 1 and 2). For example, with the absolute height of isolines of about $30-20 \mathrm{~m}$ the Littorina transgression was Early Atlantic - ca 7000 years ago, at 20-10 m - Middle Atlantic, ca 6000 years ago, and 10$5 \mathrm{~m}$ - Late Atlantic, ca 5000 years ago. 